\title{
Acute diarrhoea: Campylobacter colitis and the role of rectal biopsy
}

\author{
A. B. PRICE, J. JEWKES, AND P. J. SANDERSON \\ From Northwick Park Hospital and Clinical Research Centre, Harrow, Middlesex, UK
}

SUMMARY Campylobacter spp. were the organisms isolated most frequently from 29 consecutive patients admitted with acute diarrhoea to an infectious disease unit. Rectal biopsies taken from 21 of the patients were abnormal in all but four, and in the patients with campylobacter infection there was a characteristic proctocolitis in each case. The histopathology was similar to that described for salmonella and shigella infections but clearly different from typical ulcerative colitis and Crohn's disease. Therefore in patients with acute diarrhoea we suggest that selective culture for Campylobacter spp. should be made a routine and that rectal biopsy has an important diagnostic role, particularly in patients with negative cultures.

Sebald and Véron (1963) suggested that a group of Vibrio spp. with distinct cultural characteristics be renamed Campylobacter spp. This reclassification included Vibrio fetus and the 'related vibrios' described by King in 1957. Although it has been known since the early 1900 s that these organisms caused abortion and dysentery in cattle and domestic animals, recognition of their role in human disease is comparatively recent. The initial human isolations were from blood cultures, and the commonest isolate, Campylobacter fetus, has been associated with a wide range of clinical symptoms usually in debilitated patients. In 1972 Dekeyser et al. established a technique of selective stool culture for Campylobacter spp., and since then $C$. jejuni and $C$. coli have become accepted as a cause of human gastroenteritis (Skirrow, 1977). Until recently (Jewkes et al., 1979; Lambert et al., 1979), the intestinal pathology was thought to be limited to the small bowel. This paper shows that Campylobacter spp. are a frequent cause of infective diarrhoea and that they produce a colitis. We describe the histopathological appearances in rectal mucosa produced by these organisms and compare them with those found in patients with salmonella and shigella infection. The specificity of the mucosal changes is discussed in relation to other inflammatory bowel diseases.

\section{Methods}

The study was carried out in the infectious diseases

Received for publication 24 April 1979 unit of Northwick Park Hospital between July and November 1978. All patients aged 15 or over referred with a presumptive diagnosis of infective diarrhoea and who still had fluid stools on admission were studied. Thirty-one consecutive patients were admitted but two were subsequently excluded from the study; one was a known case of Crohn's disease, the other was shown to have ulcerative colitis.

Stool culture by conventional methods was carried out within 24 hours of admission. This included the use of the special media and conditions of incubation described by Skirrow (1977) for the isolation of Campylobacter spp. (Table 1). Isolates of this organism were Gram-negative S-shaped bacteria, which were oxidase-positive and usually catalasepositive. The clinical details and physical examination were documented by one observer (JJ) before the bacteriological results were known. Sigmoidoscopy and rectal biopsy were performed while diarrhoea was still present, and bowel preparation was not used. Twenty-one rectal biopsies were obtained. These were orientated on card and then placed in $10 \%$ formol saline. $5 \mu$ haematoxylin and eosin stained sections from routine paraffin embedded blocks were prepared and examined.

Subsequently the clinical details of the patients with campylobacter infection were compared with (1) those of the patients with salmonella or shigella infection admitted during the same observation period, and (2) the findings in patients from whom no pathogens had been isolated. For the equivalent histological comparison the rectal biopsies were coded and re-examined without knowledge of the key. The changes were graded as mild, moderate, or severe. 
Table 1 Selective technique for culturing

Campylobacter spp. (Skirrow, 1977)

\begin{tabular}{ll}
\hline Media: & $\begin{array}{l}\text { faeces directly plated onto: } \\
\text { 'Campylobacter selective agar' } \\
\text { (Oxoid blood agar with vancomycin, } \\
\text { polymyxin, and trimethoprim) }\end{array}$ \\
atmosphere: & $\begin{array}{l}\text { anaerobic jar } 2 / 3 \text { evacuated and refilled with } \\
\text { a mixture of } 80 \% \text { nitrogen, } 10 \% \mathrm{CO}_{3} \text {, and }\end{array}$ \\
& $\begin{array}{l}10 \% \text { hydrogen } \\
\text { Incubation: }\end{array}$ \\
\hline
\end{tabular}

Table 2 Bacterial isolations in 29 patients with acute diarrhoea

\begin{tabular}{ll}
\hline Campylobacter spp. & 9 \\
Salmonella spp. & 7 \\
Shigella spp. & 3 \\
Campylobacter and & 1 \\
Salmonella spp. & 9 \\
No pathogens & 9 \\
\hline
\end{tabular}

\section{Results}

Table 2 lists the results of the bacteriological cultures. Campylobacter spp. were isolated in nine cases. The stools from one patient grew both Campylobacter spp. and Salmonella spp. For convenience, the patients are subsequently divided into three groups, those from whom Campylobacter spp. were grown, those with salmonella or shigella infection, and those from whom no pathogens were isolated.

\section{CAMPYLOBACTER INFECTION}

\section{Clinical features}

The salient clinical details from the cases of campylobacter infection are shown in Table 3.

Cases 2 and 3 were initially admitted to surgical wards because of severe abdominal pain. Blood was noted in the stools in three cases, and mucus was described in six cases. A history of contact with a person suffering from diarrhoea was obtained from four patients and with suspect food in two others.
Chickens were a probable source of infection in two patients, and three patients had recently returned from abroad.

Sigmoidoscopy and rectal biopsy were performed in eight of the patients with campylobacter infection. On sigmoidoscopy the mucosa appeared normal in three cases, and in five cases it showed a mild nonspecific proctitis.

\section{Histopathology}

All eight biopsies were abnormal, and oedema was a constant finding. This produced separation of the crypts and a gap between their base and the muscularis mucosae (Figs 1,6). As a consequence of the oedema, the lamina propria appeared hypocellular or empty, and this served to accentuate other changes within it. Focal collections of polymorphs were also a constant feature though of variable intensity. In two cases they were restricted to one small area of the biopsy. The foci were present both in the lamina propria (Figs 1,2) and intermingled between the cells of the crypt and surface epithelium. Isolated crypt abscesses occurred in all cases but more characteristic was the 'incipient crypt abscess' (Figs 3, 5, 6). In these, the majority of polymorphs lay between the crypt cells and relatively small numbers within the lumen. Accompanying this change there was partial destruction or flattening of the crypt epithelial cells. The reduction in height of the crypt cells gave some crypts an elliptical shape and occasional cystic crypts were also seen. The alignment remained regular though gaps were present where crypts had been disrupted by the inflammation (Figs 4,5 ). In areas with a marked inflammatory infiltrate, there was frequently loss of the surface epithelium. Capillary congestion was prominent in all biopsies accompanied by margination of polymorphs.

The aggregates of polymorphs formed a marked contrast to the sprinkling of plasma cells and lymphocytes in the lamina propria (Figs 1, 2, 6).

Table 3 Salient clinical details in patients with campylobacter infection

\begin{tabular}{|c|c|c|c|c|c|c|c|c|}
\hline \multirow{2}{*}{$\begin{array}{l}\text { Patient } \\
\text { No. }\end{array}$} & \multirow[t]{2}{*}{ Age } & \multirow[t]{2}{*}{ Sex } & \multicolumn{2}{|l|}{ Diarrhoea } & \multirow{2}{*}{$\begin{array}{l}\text { Vomiting } \\
\text { (duration } \\
\text { in days) }\end{array}$} & \multirow[t]{2}{*}{ Pain } & \multirow[t]{2}{*}{$W B C\left(\times 10^{\circ} / L\right)$} & \multirow{2}{*}{$\begin{array}{l}\operatorname{Max} \\
\operatorname{temp}\left({ }^{\circ} \mathrm{C}\right)\end{array}$} \\
\hline & & & $\begin{array}{l}\text { Duration } \\
\text { (days) }\end{array}$ & $\begin{array}{l}\text { Max. frequency } \\
\text { stools/day }\end{array}$ & & & & \\
\hline $1^{*}$ & 23 & $\mathbf{M}$ & 6 & 10 & 1 & Severe & 4.9 & 38 \\
\hline $2+$ & 23 & $\mathbf{F}$ & 6 & 10 & 1 & Severe & $13 \cdot 5$ & 39 \\
\hline 3 & 16 & $\mathbf{M}$ & 7 & 7 & 0 & Severe & $10 \cdot 8$ & 40 \\
\hline $4+$ & 66 & $\mathbf{M}$ & 7 & 4 & 1 & Severe & $12 \cdot 1$ & 38 \\
\hline 5 & 60 & $\mathbf{F}$ & 8 & 10 & 1 & Severe & $12 \cdot 5$ & $37 \cdot 5$ \\
\hline 6 & 24 & $F$ & 9 & 12 & 1 & Mild & - & $36 \cdot 5$ \\
\hline $\begin{array}{l}0 \\
7\end{array}$ & 27 & $\mathbf{M}$ & 10 & 10 & 2 & Severe & $9 \cdot 1$ & 39 \\
\hline 8 & 16 & $\mathrm{M}$ & 10 & 5 & 2 & Mild & $4 \cdot 6$ & 372 \\
\hline $\begin{array}{l}8 \\
9\end{array}$ & $\begin{array}{l}10 \\
85\end{array}$ & $\mathbf{F}$ & 35 & 5 & 0 & Mild & 5.9 & 37 \\
\hline 10 & 18 & $\mathbf{M}$ & 70 & 12 & 14 & $\mathrm{Nil}$ & $7 \cdot 7$ & $36 \cdot 5$ \\
\hline
\end{tabular}

* Salmonella spp. also isolated

†No biopsy available 


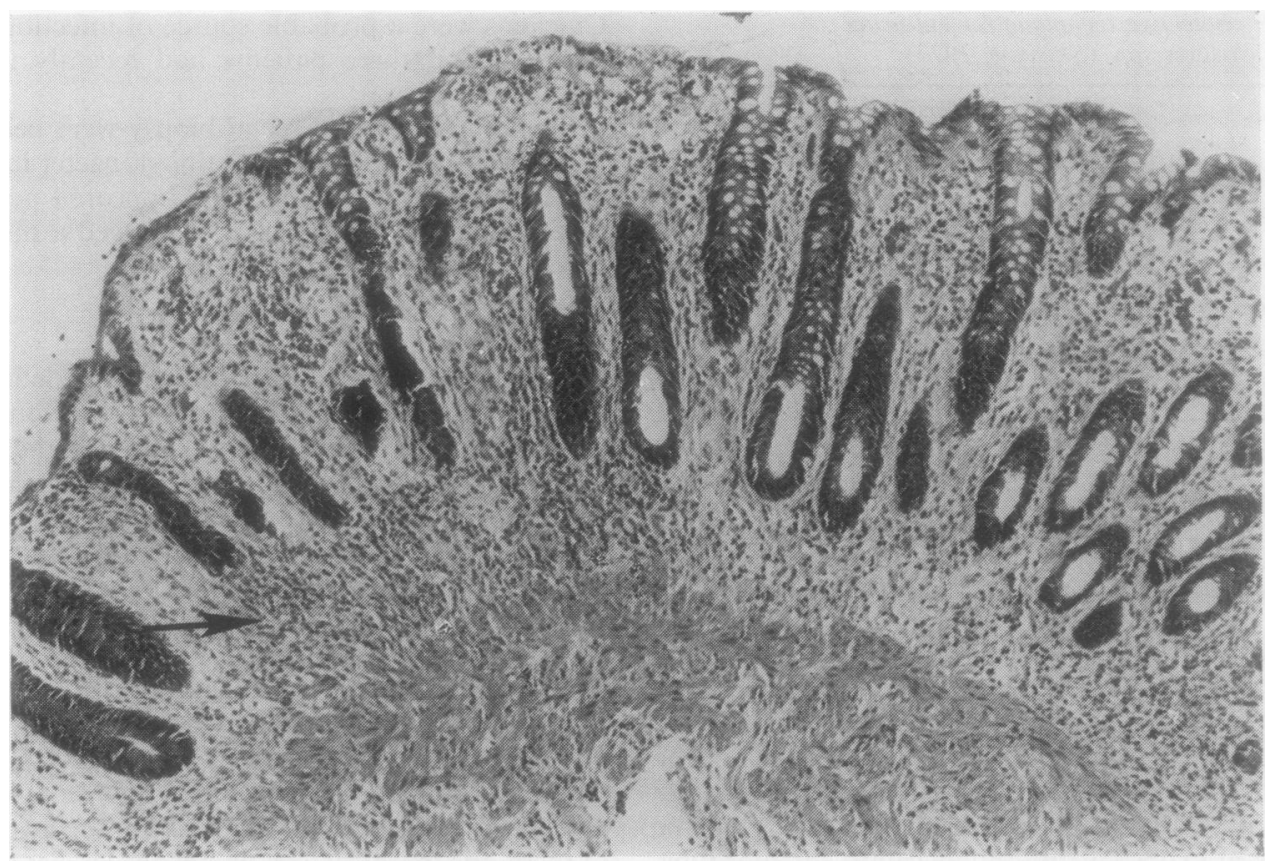

Fig. 1 Marked oedema has resulted in the separation of the base of the crypts from the muscularis mucosae. The oedema also causes the lamina propria to appear depleted of cells accentuating any aggregates of inflammatory cells (arrow). Haematoxylin and eosin $\times 103$.

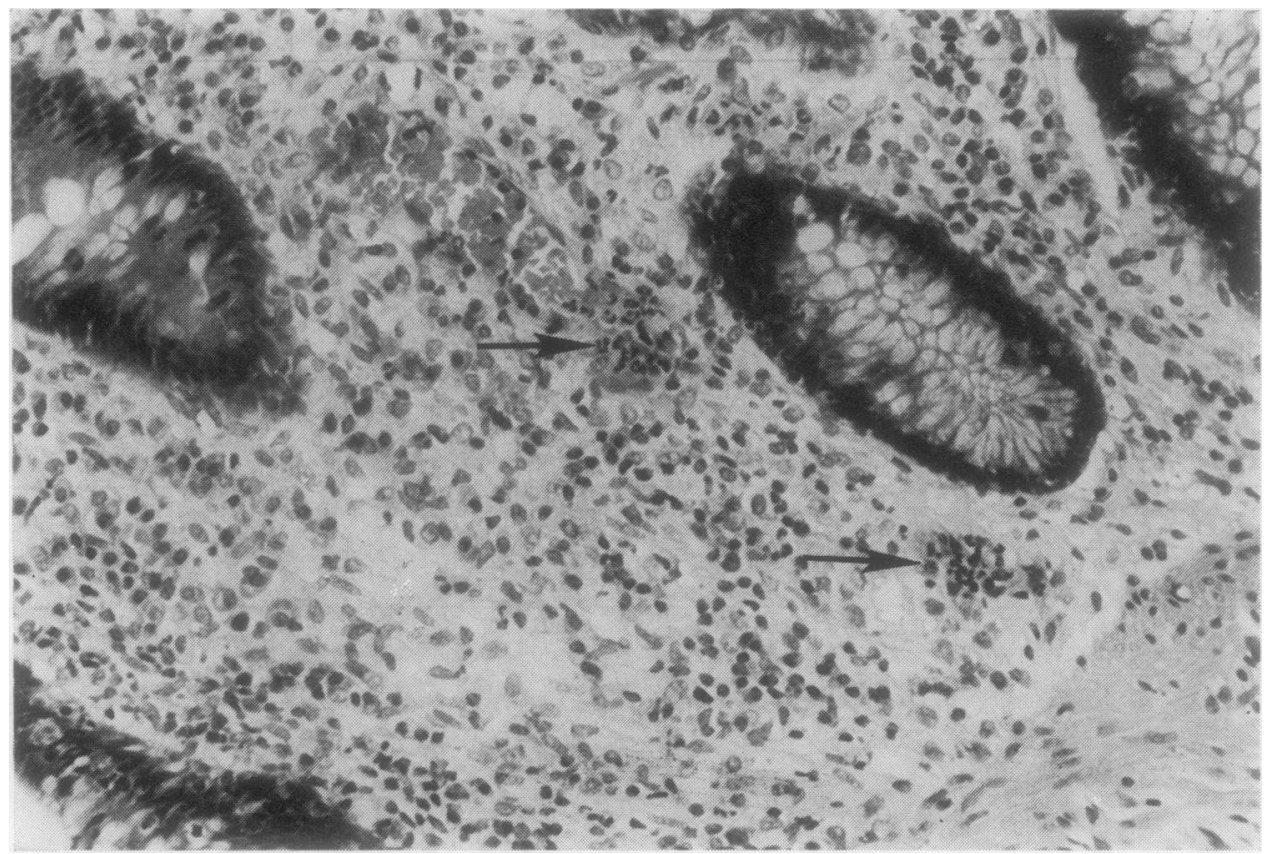

Fig. 2 Two focal aggregates of acute inflammatory cells (arrow) in the lamina propria unaccompanied by any increase in plasma cells or lymphocytes. $H$ and $E \times 2.36$. 


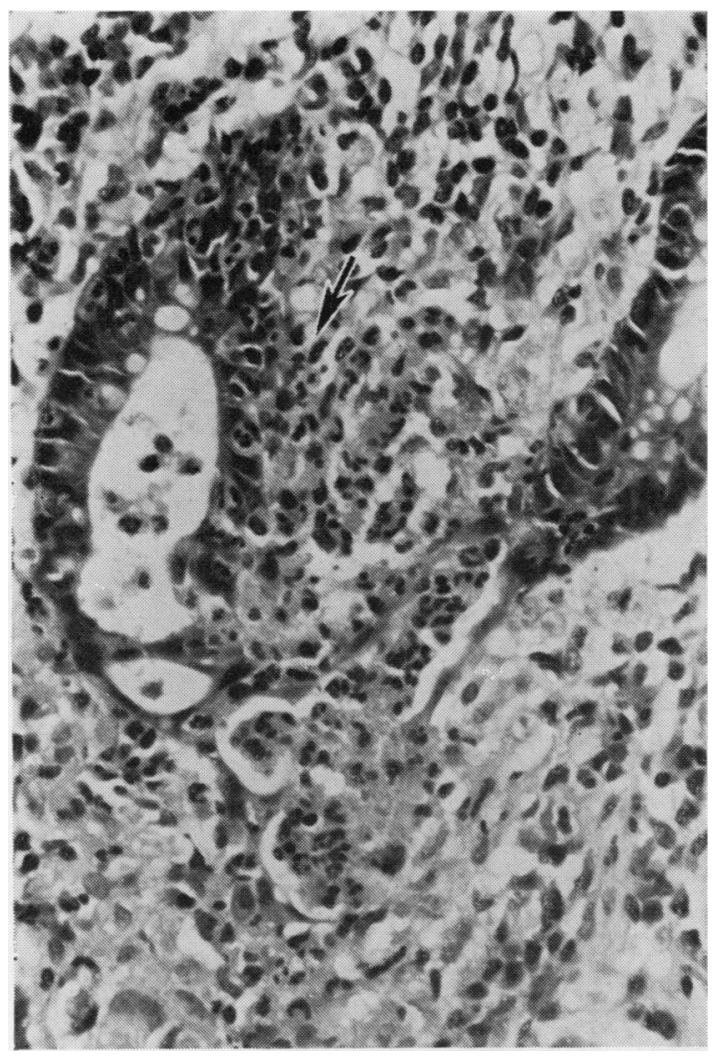

Fig. 3 An 'incipient crypt abscess' with acute inflammatory cells lying beside a crypt (arrow) and intermingled with the crypt cells, but relatively few are seen in the lumen of the crypt. Beneath there is more advanced destruction of a crypt by acute inflammatory cells. $H$ and $E \times 248$.

This was accentuated by the oedema which might have masked any absolute increase in these cells. Mucin depletion was a variable factor, and the submucosa when present appeared oedematous but free of inflammation.

COMPARISON OF THE CLINICAL AND HISTOLOGICAL FINDINGS IN THE THREE GROUPS Statistical analysis (Mann-Whitney $U$ test or onetailed Fisher's exact probability test) of the data in Tables 3 and 4 showed that certain significant differences existed between the patients with campylobacter infection and the patients from whom Salmonella spp. or Shigella spp. were isolated. Patients with campylobacter infection had more pain. $(P<0.05)$, but the maximum frequency of their diarrhoea was less $(P<0.02)$. The duration of vomiting was also less $(P<0.025)$. No other differences achieved significance. Similar analysis of the clinical values in the patients with negative cultures did not demonstrate any distinct features in this group.

The 21 biopsies from all three groups had similar histological patterns and differed only in the severity of these changes (Table 5). Only one biopsy from the group with salmonella or shigella infection showed severe changes. Four normal biopsies and three with severe abnormalities were found in the patients with negative cultures.

\section{Discussion}

The results show that Campylobacter spp. can be the commonest cause of 'gastroenteritis' admitted to an infectious disease unit (Table 2). It follows that selective culture for this group of organisms should become a routine in all cases of acute diarrhoea. The high positive culture rate overall in the study probably reflects the fact that only patients admitted with fluid stools were included and stool culture was set up within 24 hours of admission.

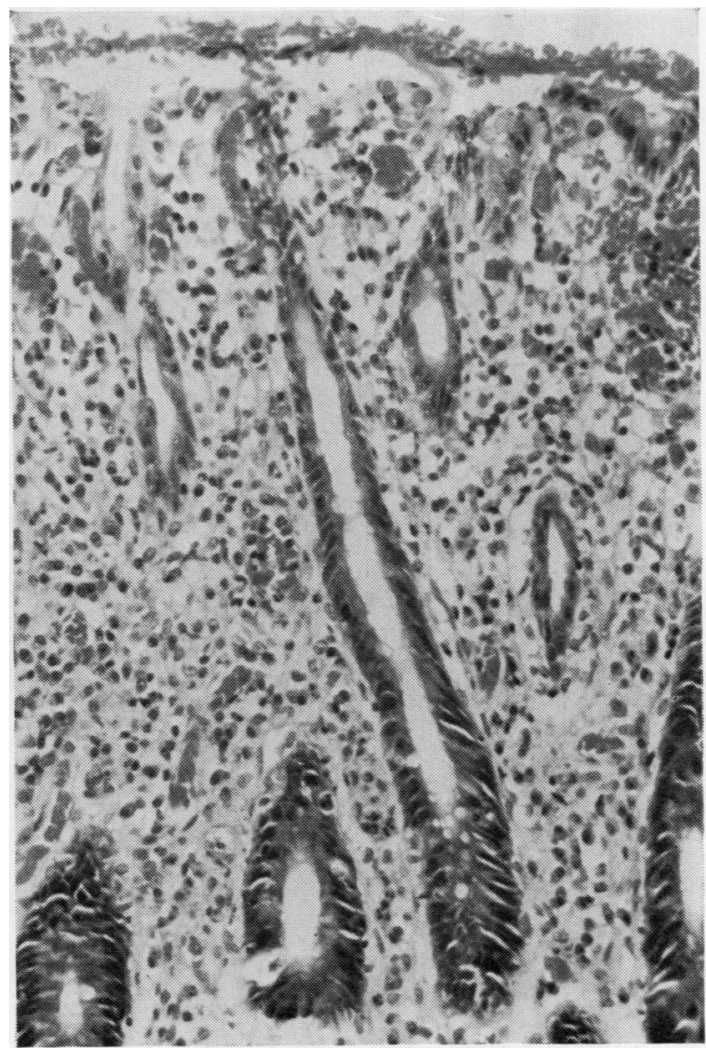

Fig. 4 Central crypt shows flattening of the lining cells while the upper halves of adjacent crypts are in a more advanced state of 'dissolution'. The crypt loss results in gaps in the crypt alignment. $H$ and $E \times 195$. 


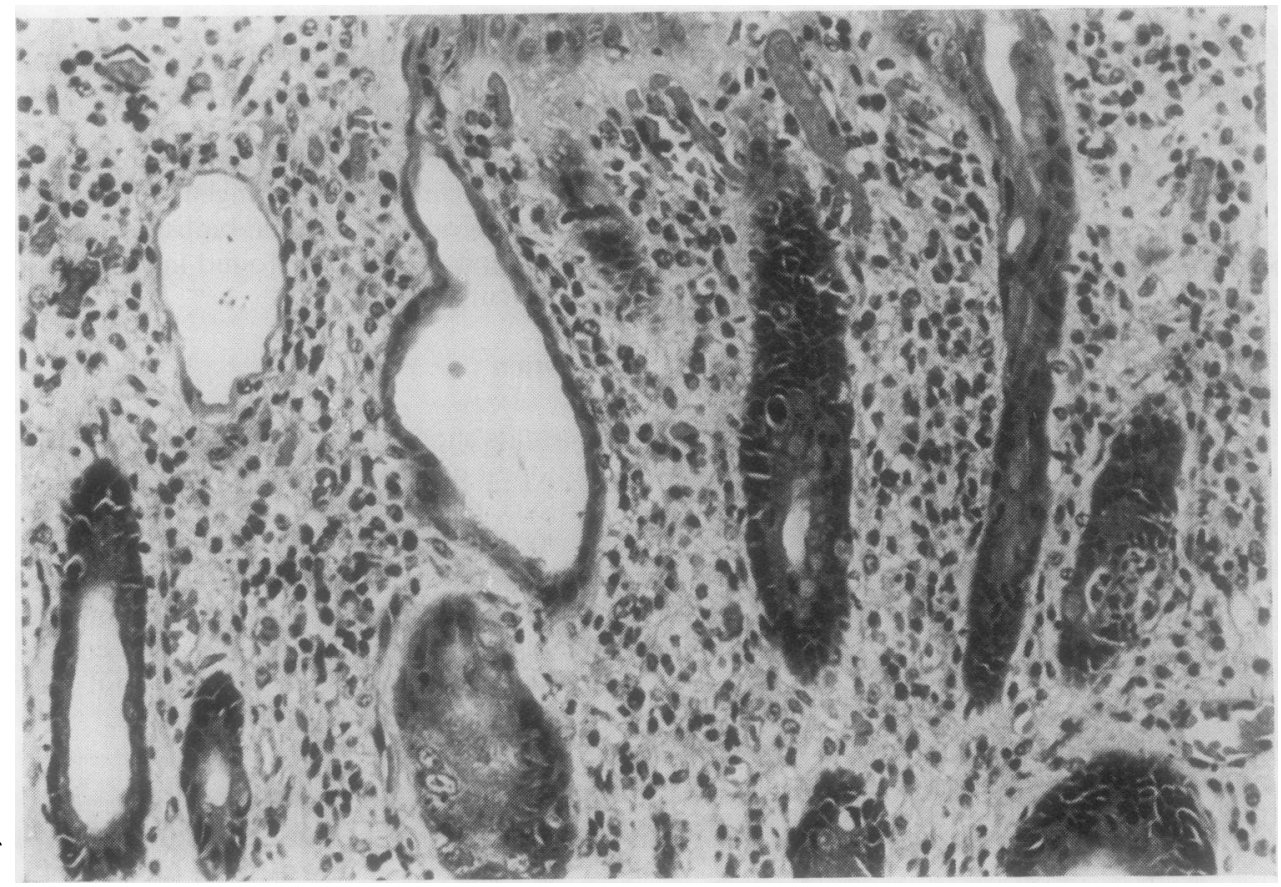

Fig. 5 An elliptical crypt is seen in the bottom left corner and a cystic crypt in the centre. On the right an 'incipient crypt abscess' is present. $H$ and $E \times 236$.

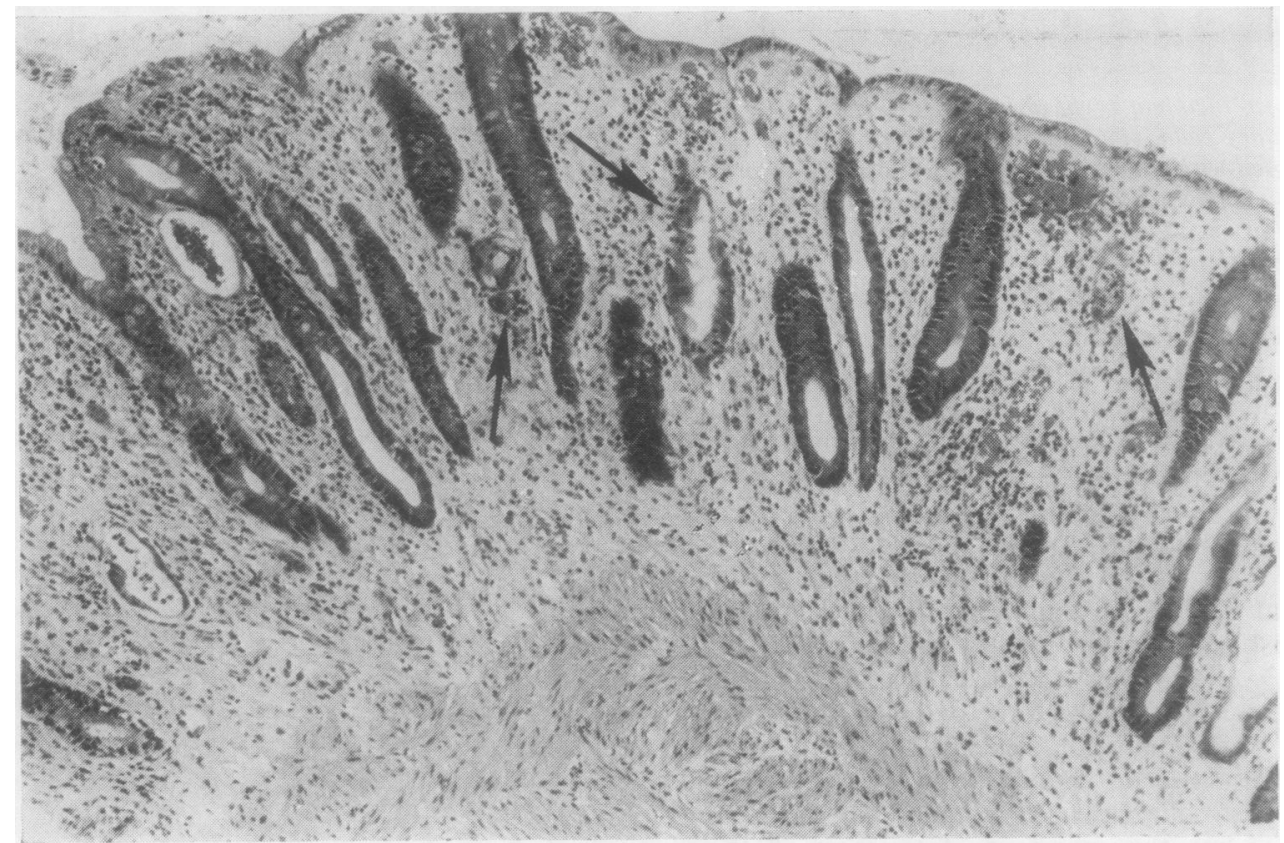

Fig. 6 Biopsy specimen characteristic of campylobacter infection and infective proctitis in general. There is marked oedema with a sprinkling of chronic inflammatory cells in the lamina propria. Some crypts show elliptical dilatation, and many are infiltrated by small clusters of acute inflammatory cells (arrows). Gaps in the lamina propria are appearing where there is crypt destruction. An established crypt abscess is seen (top left-hand corner). $H$ and $E \times 93$. 
Table 4 Salient clinical details in patients with salmonella or shigella infection

\begin{tabular}{|c|c|c|c|c|c|c|c|c|}
\hline \multirow{2}{*}{$\begin{array}{l}\text { Patient } \\
\text { No. }\end{array}$} & \multirow[t]{2}{*}{ Age } & \multirow[t]{2}{*}{ Sex } & \multicolumn{2}{|l|}{ Diarrhoea } & \multirow{2}{*}{$\begin{array}{l}\text { Vomiting } \\
\text { (duration } \\
\text { in days) }\end{array}$} & \multirow[t]{2}{*}{ Pain } & \multirow[t]{2}{*}{$W B C\left(\times 10^{\circ} / I\right)$} & \multirow{2}{*}{$\begin{array}{l}\operatorname{Max} \\
\operatorname{temp}\left({ }^{\circ} \mathrm{C}\right)\end{array}$} \\
\hline & & & $\begin{array}{l}\text { Duration } \\
\text { (days) }\end{array}$ & $\begin{array}{l}\text { Max. frequency } \\
\text { stools/day }\end{array}$ & & & & \\
\hline $\begin{array}{l}11^{*} \\
12^{*} \\
13 \\
14 \dagger \\
15 \\
16 \\
17 \\
18^{*} \\
19^{*} \dagger \\
20^{*} \dagger\end{array}$ & $\begin{array}{l}30 \\
66 \\
61 \\
64 \\
57 \\
25 \\
42 \\
23 \\
60 \\
33\end{array}$ & $\begin{array}{l}\mathbf{F} \\
\mathbf{M} \\
\mathbf{F} \\
\mathbf{M} \\
\mathbf{F} \\
\mathbf{M} \\
\mathbf{F} \\
\mathbf{F} \\
\mathbf{F} \\
\mathbf{M}\end{array}$ & $\begin{array}{r}4 \\
6 \\
8 \\
10 \\
10 \\
11 \\
12 \\
14 \\
18 \\
48\end{array}$ & $\begin{array}{r}10 \\
7 \\
30 \\
10 \\
10 \\
20 \\
50 \\
15 \\
20 \\
20\end{array}$ & $\begin{array}{r}1 \\
5 \\
1 \\
3 \\
7 \\
2 \\
5 \\
11 \\
2 \\
14\end{array}$ & $\begin{array}{l}\text { Mild } \\
\text { Mild } \\
\text { Mild } \\
\text { Nil } \\
\text { Mild } \\
\text { Mild } \\
\text { Mild } \\
\text { Severe } \\
\text { Mild } \\
\text { Mild }\end{array}$ & $\begin{array}{c}7 \cdot 5 \\
8 \cdot 5 \\
- \\
4.9 \\
3 \cdot 9 \\
5 \cdot 7 \\
- \\
9 \cdot 3 \\
8 \cdot 8 \\
10 \cdot 2\end{array}$ & $\begin{array}{l}39 \cdot 5 \\
37 \cdot 5 \\
38 \\
38 \cdot 5 \\
38 \cdot 5 \\
39 \cdot 5 \\
40 \\
37 \cdot 5 \\
36 \cdot 5 \\
40\end{array}$ \\
\hline
\end{tabular}

* No biopsy available

† Shigella spp. isolated

Table 5 Histological grading of rectal biopsies arranged in the three culture groups

\begin{tabular}{lllll}
\hline & Normal & Mild & Moderate & Severe \\
\hline Campylobacter spp. & - & 2 & 2 & 4 \\
Salmonella or Shigella spp. & - & 3 & 1 & 1 \\
No pathogens & 4 & 1 & - & 3 \\
\hline
\end{tabular}

CLINICAL FEATURES

The clinical features of campylobacter infection were similar to those described by other authors (Skirrow, 1977; Lambert et al., 1979). The severity of the abdominal pain was a particular characteristic. In two cases this had resulted in an initial admission to a surgical ward, and one patient (No. 3) underwent an appendicectomy before the correct diagnosis was made. The pain was significantly more severe than in those patients with salmonella or shigella infections. On the other hand, the patients with campylobacter infection tended to vomit less and have less frequent bowel actions. There was no evidence that the patients with negative culture results suffered a milder form of illness.

It was not the policy within the unit to prescribe antibiotic treatment for infective diarrhoea. All the patients recovered in hospital on a 'clear liquid' diet, including those with a prolonged illness before admission. Although the follow-up period is short, all the patients have remained well. No follow-up biopsies have been taken.

\section{PATHOLOGY}

Until recently (Jewkes et al., 1979; Lambert et al., 1979), intestinal disease caused by Campylobacter spp. was believed to be limited to the small bowel (Skirrow, 1977) though detailed pathology is scanty. The literature contains two necropsy reports describing a haemorrhagic jejunitis (Wheeler and Borchers, 1961; Evans and Dadswell, 1967) and a description of minor changes in a jejunal biopsy
(Cadranel et al., 1973). In the latter case, however, Giardia lamblia was also isolated. In addition, macroscopic small bowel abnormality has been observed in patients undergoing laparotomy (Skirrow, 1977). This study demonstrates that campylobacter infection also involves the large bowel, producing a proctocolitis.

The rectal biopsy from each patient with campylobacter infection was abnormal. The possibility that severe diarrhoea alone brought about the histological changes is excluded because normal biopsies were found in patients from whom pathogens were not recovered (Table 5). The abnormal histology was typical of infective colitis (Day et al., 1978; Whitehead, 1979). Most obvious was the focal mucosal infiltrate dominated by polymorphs (Figs $1,2,6)$. These foci were in marked contrast to the scattered plasma cells and lymphocytes dispersed by the oedema in the surrounding lamina propria (Figs 2, 4, 6). The infiltrate frequently produced 'incipient crypt abscesses' accompanied by a flat crypt lining (Fig. 5). The histology was similar to that seen in the biopsies from patients with salmonella or shigella infection.

In this study the most severe histological changes tended to occur in patients with campylobacter infection (Table 5), but equally severe changes are described in other infections (Day et al., 1978). Furthermore, the three patients with severe histological abnormalities but from whom pathogens were not isolated did not have typical campylobacter symptomatology. Therefore it did not prove possible to distinguish campylobacter infection from other bacterial causes of infective diarrhoea on biopsy alone.

INFLAMMATORY BOWEL DISEASE

The patients in this study represent a small group, but the results have a bearing on a common problem, the differential diagnosis of infective protocolitis 
from ulcerative colitis and Crohn's disease. There are two aspects to consider: firstly, whether finding the typical histopathology of infective proctocolitis in a rectal biopsy is sufficiently characteristic to exclude a diagnosis of ulcerative colitis or Crohn's disease; and, secondly, the incidence of non-specific or even misleading biopsy histology in patients with infective diarrhoea.

Most histopathologists would agree that the histology of infective proctitis, while characteristic, is not diagnostic and that a considerable overlap with non-specific inflammatory bowel disease exists (Morson and Dawson, 1972; Whitehead, 1979). The literature on the diagnostic accuracy of such appearances is biased for it deals only with patients admitted to infectious disease units rather than patients attending gastroenterological outpatient departments (Day et al., 1978; Dickinson et al., 1979; Lambert et al., 1979). In the series of Dickinson et al. (1979), no patient with non-specific inflammatory bowel disease on clinical assessment had the typical histopathology of infective proctitis on rectal biopsy. The results of Day et al. (1978) were similar. They found that when ulcerative colitis and infection coexisted the changes of the former dominated the histology. In our own series, one patient was excluded who developed toxic megacolon clearly due to ulcerative colitis. The initial biopsy, however, had been confidently labelled 'infective'. It seems reasonable to suggest that a rectal biopsy characteristic of infective proctocolitis will only rarely be misleading when considered in conjuction with a careful clinical assessment. It is, therefore, a useful short-term diagnostic guide in patients with culture-negative acute diarrhoea. The reported yield of pathogenic organisms from stool culture in patients with acute diarrhoea is usually low (Paton, 1974; Skirrow, 1977; Dickinson et al., 1979), and for this reason rectal biopsy should be used more frequently in the investigation of this group of patients.

Although it was not our experience in this study, the histopathology of rectal biopsy in infective diarrhoea can be non-specific and may even show appearances that suggest ulcerative colitis or Crohn's disease (Dickinson et al., 1979; Lambert et al., 1979). Thirteen of 36 biopsies from patients with a clinical diagnosis of infective diarrhoea in the series of Dickinson et al. (1979) had non-specific microscopy, while $10 \%$ were interpreted as more like ulcerative colitis. In 11 cases of campylobacter colitis seen by Lambert et al. (1979), only one rectal biopsy was typically 'infective' and three were thought to resemble ulcerative colitis. On the other hand, in the series of Day et al. (1978), in salmonella colitis only two out of 22 patients had atypical biopsies. In our series, none of the biopsies from patients from whom a pathogen was isolated suggested ulcerative colitis or Crohn's disease, but four were normal in patients without pathogens. The variable results in the literature probably reflect the timing of the biopsy in the history of the disease as well as differences in interpretation between histopathologists. In culturenegative patients with acute diarrhoea and a discrepancy between clinical and pathological diagnoses, or with non-specific histopathology, one has to rely on follow-up biopsies. The appearances in most cases of infective diarrhoea will revert permanently to normal within a few months (Dickinson et al., 1979).

Certain limited conclusions can be drawn from this particular study. Campylobacter spp. must now be added to the list of bacteria capable of causing the characteristic histology of infective proctitis in a rectal biopsy. The appearance is similar to that produced by salmonella or shigella infection. It is sufficiently different from typical ulcerative colitis or Crohn's disease to make rectal biopsy a useful diagnostic guide in the management of culturenegative acute diarrhoea.

We are grateful to Dr Hillas Smith and Dr H. E. Larson for allowing us to study patients under their care; we also thank Mrs G. Sowter and the Department of Histopathology, Northwick Park Hospital, for technical help, John Clark for photography, and Miss J. Jones for secretarial assistance.

\section{References}

Cadranel, S., Rodesch, P., Butzler, J. P., and Dekeyser, P. (1973). Enteritis due to 'related Vibrio' in children. American Journal of Diseases of Children, 126, 152-155.

Day, D. W., Mandal, B K., and Morson, B. C. (1978). The rectal biopsy appearances in Salmonella colitis. Histopathology, 2, 117-131.

Dekeyser, P., Gossuin-Detrain, M., Butzler, J. P., and Sternon, J. (1972). Acute enteritis due to related vibrio: first positive stool cultures. Journal of Infectious Diseases, 125, 390-392.

Dickinson, R. J., Gilmour, H. M., and McClelland, D. B. L. (1979). Rectal biopsy in patients presenting to an infectious diseases unit with diarrhoeal disease. Gut, 20, 141-148.

Evans, R. G., and Dadswell, J. V. (1967). Human vibriosis (Letter). British Medical Journal, 2, 240.

Jewkes, J., Sanderson, P. J., and Price, A. B. (1979). Campylobacter enterocolitis (abstract). Gut, 20, A445.

King, E. O. (1957). Human infections with Vibrio fetus and a closely related Vibrio. Journal of Infectious Diseases, 101, 119-128.

Lambert, M. E., Schofield, P. F., Ironside, A. G., and Mandal, B. K. (1979). Campylobacter colitis. British Medical Journal, 1, 857-859.

Morson, B. C., and Dawson, I. M. P. (Eds.) (1972). 
Gastrointestinal Pathology, p. 449. Blackwell, Oxford. Paton, A. (1974). Gastrointestinal disorders. British Medical Journal, 4, 522-524.

Sebald, M., and Véron, M. (1963). Teneur en bases de l'ADN et classification des Vibrions. Annales de l'Institut Pasteur, 105, 897-910.

Skirrow, M. B. (1977). Campylobacter enteritis: a 'new' disease. British Medical Journal, 2, 9-11.

Wheeler, W. E., and Borchers, J. (1961). Vibrionic enteritis in infants. American Journal of Diseases of Children, 101, 60-66.

Whitehead, R. (1979). Mucosal Biopsy of the Gastrointestinal Tract, 2nd edition, pp. 202-205. W. B. Saunders, Philadelphia and London.

Requests for reprints to: Dr A. B. Price, Northwick Park Hospital, Watford Road, Harrow, Middlesex HA1 3UJ, UK. 